\title{
Koninginins N-Q, Polyketides from the Endophytic Fungus Trichoderma koningiopsis Harbored in Panax notoginseng
}

\author{
Kai Liu $\cdot$ Ya-Bin Yang $\cdot$ Jin-Lian Chen $\cdot$ \\ Cui-Ping Miao $\cdot$ Qiang Wang $\cdot$ Hao Zhou $\cdot$ \\ You-Wei Chen · Yi-Qing Li $\cdot$ Zhong-Tao Ding • \\ Li-Xing Zhao
}

Received: 28 October 2015/Accepted: 20 December 2015/Published online: 11 January 2016

(C) The Author(s) 2016. This article is published with open access at Springerlink.com

\begin{abstract}
Four new fungal polyketides named koninginins N-Q (1-4), together with four known analogues (5-8), were isolated from the endophytic fungus Trichoderma koningiopsis YIM PH30002 harbored in Panax notoginseng. Their structures were determined on the basis of spectral data interpretation. These compounds were evaluated for their antifungal activity, nitric oxide inhibition, and anticoagulant activity.
\end{abstract}

\section{Graphical Abstract}
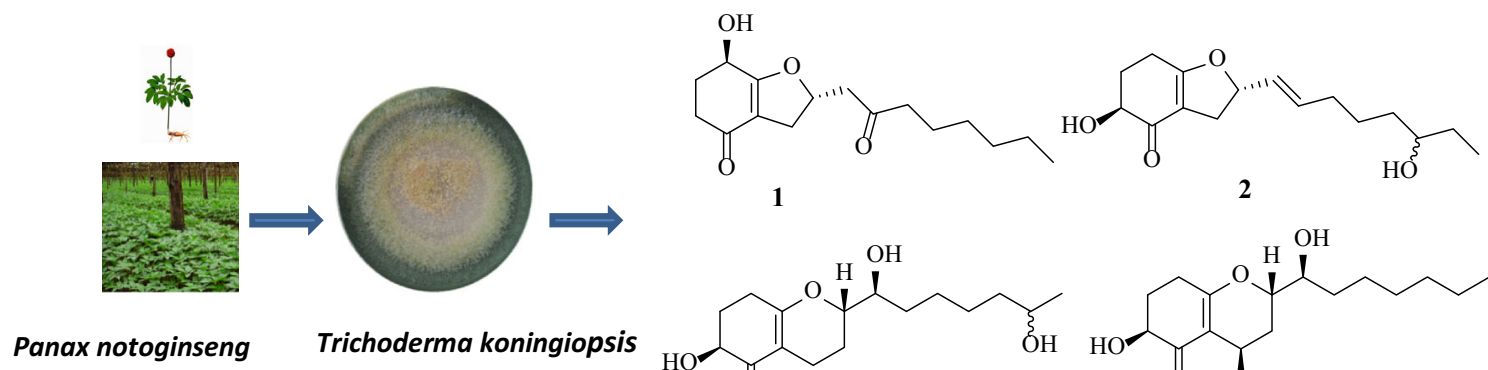

1<smiles>CC(O)CCCCC(O)C12CCCC(=O)C(O)CC1O2</smiles><smiles>CCCCCCC(O)C1CC(OCC)C2=C(CCC(O)C2=O)O1</smiles>

Keywords Trichoderma koningiopsis $\cdot$ Polyketide $\cdot$ Antifungal activity $\cdot$ Bioactivity assay $\cdot$ Koninginin

K. Liu and Y.-B. Yang have contributed equally to this paper.

Electronic supplementary material The online version of this article (doi:10.1007/s13659-015-0085-z) contains supplementary material, which is available to authorized users.

K. Liu · C.-P. Miao · Q. Wang · Y.-W. Chen · Y.-Q. Li ·

L.-X. Zhao $(\bowtie)$

Yunnan Institute of Microbiology, School of Life Science,

Yunnan University, Kunming 650091, People's Republic of

China

e-mail: zlx70@163.com
Y.-B. Yang $\cdot$ H. Zhou $\cdot$ Z.-T. Ding $(\bowtie)$

Key Laboratory of Medicinal Chemistry for Natural Resource, Ministry of Education, School of Chemical Science and Technology, Yunnan University, Kunming 650091, People's Republic of China

e-mail: ztding@ynu.edu.cn

\section{J.-L. Chen}

School of Energy and Environment Science, Yunnan Normal University, Kunming 650092, People's Republic of China 
<smiles>CCCCCCC(=O)C[C@@H]1CC2=C(O1)[C@@H](O)CCC2=O</smiles><smiles>CCCCCC[C@H](O)[C@H]1C[C@@H](OC)C2=C(CC[C@@H](O)C2=O)O1</smiles><smiles>CCCCCC[C@H](O)[C@H]1CCC2=C(CC[C@@H](O)C2=O)O1</smiles><smiles>CCCCCC[C@H](O)[C@H]1CCC2=C(O1)[C@@H](O)CCC2=O</smiles>

6<smiles>CC(=O)CCCC[C@@H](O)[C@H]1CCC2=C(CC[C@@H](O)C2=O)O1</smiles><smiles>CCCCCC[C@H](O)[C@H]1C[C@@H](OC)C2=C(O1)[C@H](O)CCC2=O</smiles>

7

8

Fig. 1 Chemical structures of compounds 1-8 from T. koningiopsis YIM PH30002

\section{Introduction}

Endophytic microorganisms, residing in the living tissues of the host plant and forming complex relationships with the host, are to be found in every plant on earth. Species of Trichoderma, ubiquitous in the environment including plant and soil, produce a plethora of substances with potential use for modern agriculture, and industry [1, 2]. Some Trichoderma species can be used to enhancing plant growth and resistance to the biotic and abiotic stresses, such as antagonizing plant-pathogenic fungi, stimulating plant growth and defense responses, and inducing salt tolerance [3, 4]. At global level, Trichoderma species are widely used as a powerful biocontrol agent for plant diseases [5]. Chemical exploitation of Trichoderma spp. afforded a diverse of bioactive secondary metabolites [69]. Over the course of our ongoing search for new naturally occurring bioactive products from endophytic fungi associated with famous Chinese traditional medicine, Panax notoginseng [10], the chemical investigation of endophytic fungus Trichoderma koningiopsis YIM PH30002 was found with inhibiting the growth of some phytopathogenic fungi [11]. Four new metabolites named koninginins N-Q (1-4), together with four known koninginins B (5), E (6), J (7), and 7-O-methylkoninginin D (8) were isolated [9, 1214] (Fig. 1). In the present paper, we report the isolation, structural elucidation and bioactivities of these fungal polyketides.

\section{Results and Discussion}

Compound $\mathbf{1}$ was obtained as oil. The molecular formula of $\mathbf{1}$ was determined to be $\mathrm{C}_{16} \mathrm{H}_{24} \mathrm{O}_{4}$ by analysis of its HRESI-MS spectrum and NMR data (Table 1). A detailed analysis of its NMR data revealed that its chemical structure was highly similar to trichodermaketone $\mathrm{C}$ [9]. The $\mathrm{OH}$ group connected to $\mathrm{C}-4$ was determined by the correlations from $\mathrm{H}-4$ to $\mathrm{C}-5$, and $\mathrm{C}-6$ in the $\mathrm{HMBC}$ spectrum and the correlation from $\mathrm{H}-2$ to $\mathrm{H}-4$ in the ${ }^{1} \mathrm{H}-{ }^{1} \mathrm{H}$ COSY spectrum. The connection of C-5 to $\mathrm{C}-8$ by an oxygen atom was determined by the HMBC correlations from $\mathrm{H}-7$ to $\mathrm{C}-5,6$ and the COSY correlation from $\mathrm{H}-7$ to $\mathrm{H}-9$. The carbonyl was placed at $\mathrm{C}-10$ according to the correlations from H-9, 11, 12 to $\mathrm{C}-10$ in the HMBC spectrum (Fig. 2). The relative stereochemistry at $\mathrm{H}_{4}-\mathrm{H}_{8}$ of compound $\mathbf{1}([\alpha]=-68.3)$ was determined to the same as trichodermaketone $\mathrm{C}$ by comparing the NMR data and optical rotation value of trichodermaketone $\mathrm{C}([\alpha]=-92.5)$ [9]. A negative Cotton effect at $292 \mathrm{~nm}(\Delta \varepsilon-2.023)$ for the $\mathrm{n} \rightarrow \pi^{*}$ transition in the circular dichroism (CD) spectrum (Fig. 3) of 1 suggested that the absolute configuration of C-4 was 4R. 
Table $1{ }^{1} \mathrm{H}$ and ${ }^{13} \mathrm{C}$ NMR Data of $\mathbf{1 - 4}$ in $\mathrm{CDCl}_{3}$ ( $\delta$ in ppm, $J$ in $\mathrm{Hz}$ )

\begin{tabular}{|c|c|c|c|c|c|c|c|c|}
\hline \multirow[t]{2}{*}{ Position } & \multicolumn{2}{|l|}{$\mathbf{1}^{\mathrm{a}}$} & \multicolumn{2}{|l|}{$2^{\mathrm{b}}$} & \multicolumn{2}{|l|}{$3^{\mathrm{b}}$} & \multicolumn{2}{|l|}{$4^{\mathrm{a}}$} \\
\hline & $\delta_{\mathrm{H}}$ & $\delta_{\mathrm{c}}$ & $\delta_{\mathrm{H}}$ & $\delta_{\mathrm{c}}$ & $\delta_{\mathrm{H}}$ & $\delta_{\mathrm{c}}$ & $\delta_{\mathrm{H}}$ & $\delta_{\mathrm{c}}$ \\
\hline 1 & & 194.9 & & 195.2 & & 198.5 & & 197.7 \\
\hline 2 & $2.44,2.33(\mathrm{~m})$ & 35.0 & $4.10(\mathrm{dd}, 5.6)$ & 71.9 & $4.07(\mathrm{dd}, 5.6)$ & 71.4 & $4.15(\mathrm{dd}, 5.2)$ & 71.0 \\
\hline 3 & $2.31,2.03(\mathrm{~m})$ & 31.3 & $2.42,1.89(\mathrm{~m})$ & 30.7 & $2.36,1.79(\mathrm{~m})$ & 29.4 & $2.37,1.78(\mathrm{~m})$ & 29.2 \\
\hline 4 & $4.57(\mathrm{q}, 6.4)$ & 64.1 & $2.56(\mathrm{~m})$ & 23.4 & $2.61,2.48(\mathrm{~m})$ & 27.6 & $2.64,2.47(\mathrm{~m})$ & 27.3 \\
\hline 5 & & 175.0 & & 178.3 & & 171.6 & & 173.1 \\
\hline 6 & & 113.4 & & 110.8 & & 109.6 & & 110.5 \\
\hline 7 & $3.06,2.44(\mathrm{~m})$ & 32.5 & $3.09,2.56(\mathrm{~m})$ & 32.2 & $2.61,2.09(\mathrm{~m})$ & 18.1 & $4.39(\mathrm{~m})$ & 65.4 \\
\hline 8 & $5.28(\mathrm{~m})$ & 82.2 & $5.28(\mathrm{~m})$ & 87.9 & $1.95,1.59(\mathrm{~m})$ & 23.1 & $2.04,1.63(\mathrm{~m})$ & 28.1 \\
\hline 9 & $2.97,2.72(\mathrm{~m})$ & 48.8 & $5.59(\mathrm{~m})$ & 128.5 & $3.76(\mathrm{~m})$ & 81.2 & $4.13(\mathrm{~m})$ & 77.0 \\
\hline 10 & & 207.9 & $5.82(\mathrm{~m})$ & 135.9 & $3.69(\mathrm{~m})$ & 73.5 & $3.65(\mathrm{~m})$ & 72.9 \\
\hline 11 & $2.44(\mathrm{~m})$ & 44.1 & $2.10(\mathrm{~m})$ & 32.5 & $1.62(\mathrm{~m})$ & 33.1 & $1.64(\mathrm{~m})$ & 33.2 \\
\hline 12 & $1.56(\mathrm{~m})$ & 23.9 & $1.54(\mathrm{~m})$ & 25.2 & $1.46(\mathrm{~m})$ & 26.0 & $1.30(\mathrm{~m})$ & 22.6 \\
\hline 13 & $1.28(\mathrm{~m})$ & 31.9 & $1.51(\mathrm{~m})$ & 36.7 & $1.62(\mathrm{~m})$ & 25.8 & $1.30(\mathrm{~m})$ & 29.3 \\
\hline 14 & $1.28(\mathrm{~m})$ & 29.2 & $3.56(\mathrm{~m})$ & 73.5 & $1.46(\mathrm{~m})$ & 39.5 & $1.30(\mathrm{~m})$ & 31.7 \\
\hline 15 & $1.28(\mathrm{~m})$ & 22.8 & $1.50(\mathrm{~m})$ & 30.4 & $3.82(\mathrm{~m})$ & 68.4 & $1.30(\mathrm{~m})$ & 22.6 \\
\hline 16 & $0.88(\mathrm{t}, 6.0)$ & 14.4 & $0.94(\mathrm{t}, 7.6)$ & 10.2 & $1.20(\mathrm{~d}, 6.4)$ & 24.0 & $0.90(\mathrm{t}, 6.5)$ & 14.0 \\
\hline $\mathrm{OCH}_{3}$ & & & & & & & $3.38(\mathrm{~s})$ & 56.9 \\
\hline
\end{tabular}

a ${ }^{1} \mathrm{H}$ NMR was recorded at $400 \mathrm{MHz}$, and ${ }^{13} \mathrm{C}$ NMR was recorded at $100 \mathrm{MHz}$

b ${ }^{1} \mathrm{H}$ NMR was recorded at $500 \mathrm{MHz}$, and ${ }^{13} \mathrm{C}$ NMR was recorded at $125 \mathrm{MHz}$

Fig. 2 Key ${ }^{1} \mathrm{H}-{ }^{1} \mathrm{H}$ COSY and HMBC correlations of compounds 1-4

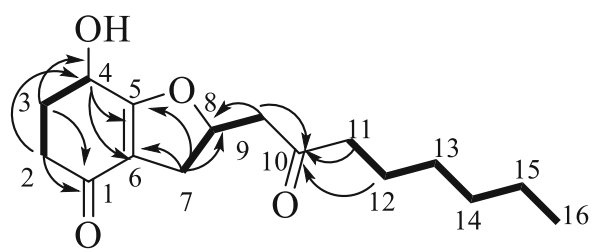

1

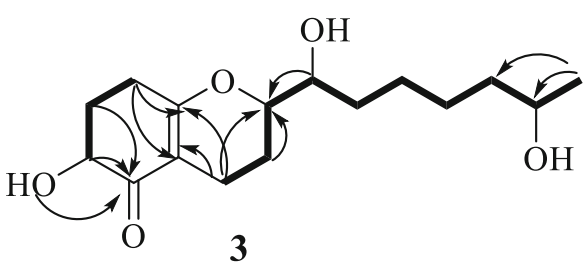

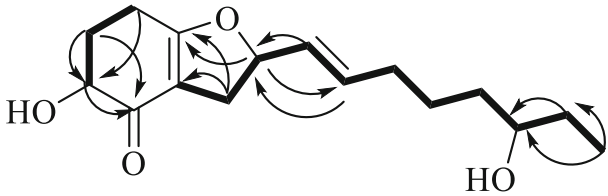

2

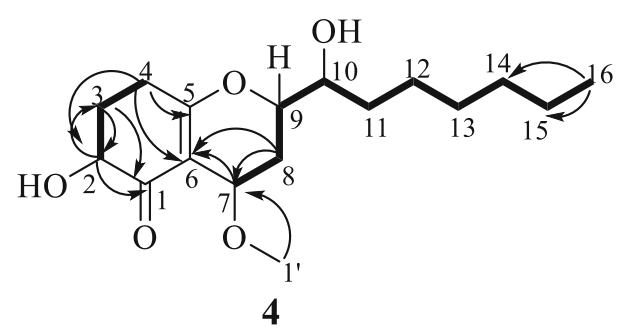

$\longrightarrow \mathrm{COSY} \longrightarrow \mathrm{HMBC}$

The molecular formula of $\mathbf{2}$ was established as $\mathrm{C}_{16} \mathrm{H}_{24} \mathrm{O}_{4}$ by the HRESI-MS and NMR data. Compound $\mathbf{2}$ shared the same skeleton as compound $\mathbf{1}$ according to the NMR data (Table 1). The $\mathrm{OH}$ group connected to $\mathrm{C}-2$ was confirmed by the HMBC correlation from $\mathrm{H}-2$ to $\mathrm{C}-1$ and the COSY correlations from $\mathrm{H}-2$ to $\mathrm{H}-4$. The connections of $\mathrm{C}-5$ to $\mathrm{C}-8$ by an oxygen atom and $\mathrm{C}_{9}-\mathrm{C}_{10}$ to $\mathrm{C}-8$ were determined by the correlations from $\mathrm{H}-8$ to $\mathrm{C}-5, \mathrm{H}-7$ to $\mathrm{C}-5$ and C-6 in HMBC spectrum, and the correlations from H-7 to $\mathrm{H}-10$ in ${ }^{1} \mathrm{H}-{ }^{1} \mathrm{H}$ COSY spectrum. Another $\mathrm{OH}$ group was assigned to $\mathrm{C}-14$ by the $\mathrm{HMBC}$ correlations from $\mathrm{H}-16$ to C-14, C-15 (Fig. 2). The presence of a trans-double bond was revealed by the corresponding carbon signals at $\delta_{\mathrm{C}}$ 128.5 (C-9) and 135.9 (C-10). The absolute configurations of compound 2 in $\mathrm{H}-2$ and $\mathrm{H}-8$ were determined the same as these of trichoketide $\mathrm{B}$ by comparing the $\mathrm{CD}$ spectrum 

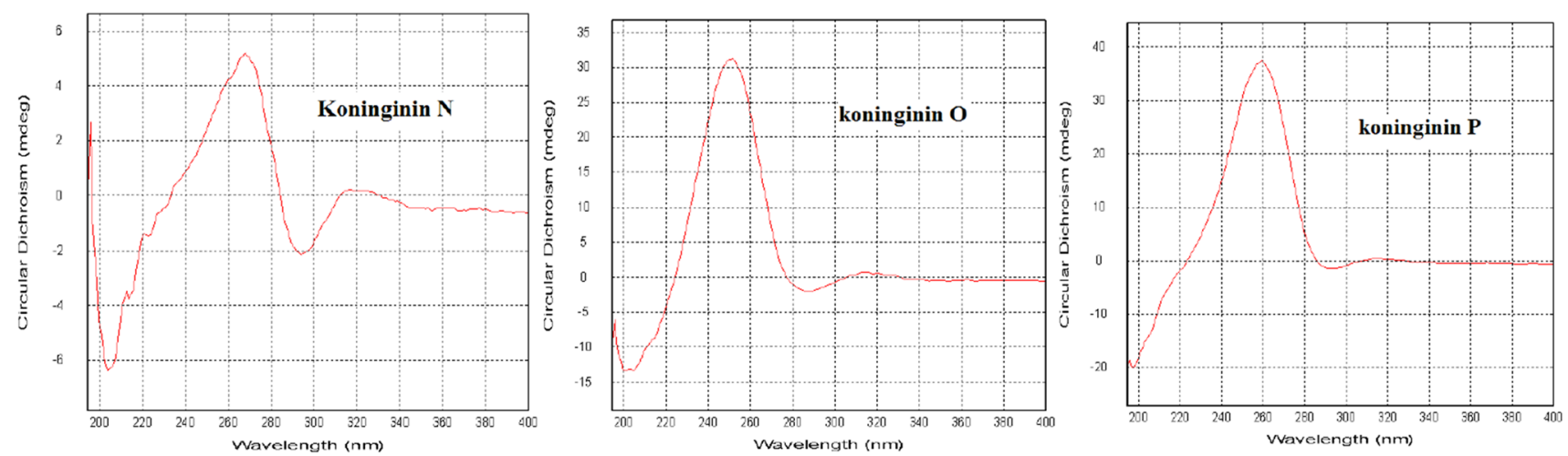

Fig. 3 The CD spectra of compounds 1-3

(Fig. 3), the NMR data and the optical rotation value of trichoketide B [15].

Compound 3 was isolated as pale-yellow oil. The molecular formula of 3 was determined to be $\mathrm{C}_{16} \mathrm{H}_{26} \mathrm{O}_{5}$ by its HRESI-MS and NMR data. After detailed analysis of the ${ }^{1} \mathrm{H}$ and ${ }^{13} \mathrm{C}$ NMR data (Table 1), the skeleton of compound $\mathbf{3}$ was elucidated to be the same as compound $\mathbf{7}$. The $\mathrm{OH}$ group connected to $\mathrm{C}-2$ was confirmed by the $\mathrm{HMBC}$ correlations from $\mathrm{H}-2$ to $\mathrm{C}-1$ and the COSY correlations from $\mathrm{H}-2$ to $\mathrm{H}-4$. The connection of $\mathrm{C}-5$ to $\mathrm{C}-9$ by the oxygen atom and $\mathrm{OH}$ connected to $\mathrm{C}-10$ were determined by the COSY correlations from $\mathrm{H}-7$ to $\mathrm{H}-10$ and HMBC correlations from $\mathrm{H}-7$ to C-5, C-6, C-9, and H-10 to $\mathrm{C}-9$. The $\mathrm{OH}$ group connection to $\mathrm{C}-15$ was confirmed by the HMBC correlation from $\mathrm{H}-16$ to $\mathrm{C}-14, \mathrm{C}-15$ and COSY correlations from $\mathrm{H}-16$ to $\mathrm{H}-15$ (Fig. 2). In the ${ }^{1} \mathrm{H}$ NMR spectrum, a coupling constant $(J=5.6 \mathrm{~Hz})$ was observed for $\mathrm{H}-2$, which required a trans-diequatorial relationship between the oxymethine proton $(\mathrm{H}-2)$ and $\mathrm{H}-3 \alpha$. The absolute configurations of compound 3 in $\mathrm{H}-9$, and $\mathrm{H}-10$ were determined to be the same as that of koninginin $\mathrm{B}$ also isolated from one strain of T. koningiopsis [12] by the comparison of NMR spectra, CD spectrum (Fig. 3), and their biogenesis.

The molecular formula of $\mathbf{4}$ was elucidated as $\mathrm{C}_{17} \mathrm{H}_{28} \mathrm{O}_{5}$ by analysis of its HRESI-MS spectrum and NMR data (Table 1). A detailed analysis of its NMR data revealed a highly similar structure to koninginin $F$ [12]. The full assignments of its ${ }^{1} \mathrm{H}$ and ${ }^{13} \mathrm{C}$ NMR (Table 1) were obtained by 2D NMR (Fig. 2). Two oxygen atoms were assigned to C-7 and C-9, respectively, according to HMBC correlations from $\mathrm{H}-7$ to $\mathrm{C}-6$, and the COSY correlations from $\mathrm{H}-7$ to $\mathrm{H}-9$. The $\mathrm{OH}$ group at $\mathrm{C}-2$ was determined by the correlation between $\mathrm{H}-2$ and $\mathrm{C}-1$ in the HMBC spectrum, and another $\mathrm{OH}$ group was placed at $\mathrm{C}-10$ on the basis of the cross peak of H-9 to $\mathrm{H}-10$ in the ${ }^{1} \mathrm{H}-{ }^{1} \mathrm{H}$ COSY spectrum. The methoxy group was elucidated by the correlation from $\mathrm{OCH}_{3}$ to $\mathrm{C}-7$ in the $\mathrm{HMBC}$ spectrum. In the ${ }^{1} \mathrm{H}$ NMR, a coupling constant $(J=5.2 \mathrm{~Hz})$ was observed for $\mathrm{H}-2$, which required a trans-diequatorial relationship between the oxymethine proton $(\mathrm{H}-2)$ and $\mathrm{H}-3 \alpha$. The stereochemistry of C-7, C-9, and C-10 in compound 4 was the same as that of koninginin $\mathrm{F}$ also isolated from one strain of T. koningiopsis by the NMR comparison, CD spectrum (Fig. 3), and their biogenesis [12].

The absolute configurations of $\mathbf{2 - 4}$ were assigned as $2 \mathrm{~S}$, similar to the known compounds, on the bases of $\mathrm{CD}$ spectral analyses and their biosynthetic pathway (Fig. 3) $[8,15]$.

The antifungal activities of compounds 1-8 were challenged with the phytopathogenic fungi, Fusarium oxysporum, F. solani, F. flocciferum, Plectosphaerella cucumerina, Alternaria panax which are causes of root rot diseases of $P$. notoginseng [16]. Koninginin $O(2)$ and koninginin $\mathrm{Q}(5)$ showed the weak activity against $F$. oxysporum, $P$. cucumerina, with an MIC of $128 \mu \mathrm{g} / \mathrm{mL}$. 7-O-methylkoninginin $\mathrm{D}(\mathbf{8})$ showed weak activity against $P$. cucumerina with an MIC of $128 \mu \mathrm{g} / \mathrm{mL}$. Other compounds present no antifungal activity as their MICs $>128 \mu \mathrm{g} / \mathrm{mL}$. The positive control compound, nystatin showed antifungal activity with MICs at $32 \mu \mathrm{g} / \mathrm{mL}$. Compound 1 showed low active in the NO inhibitory tests with $\mathrm{IC}_{50}>25 \mu \mathrm{M}$ (MG 132 at $0.18 \mu \mathrm{M}$ ), and compound 5 showed no obvious anticoagulant activity with APTT at $39.8 \pm 0.42 \mathrm{~s}(\mathrm{LMWH}$ at $135.8 \pm 0.85 \mathrm{~s})$.

\section{Experimental Section}

\subsection{General}

Optical rotations were measured on a Perkin-Elmer 341 automatic polarimeter (Perkin-Elmer). UV spectra were recorded in $\mathrm{MeOH}(1 \mathrm{mg} / 50 \mathrm{~mL})$ on a UV $210 \mathrm{~A}$ 
spectrophotometer (Shimadzu). NMR spectra were recorded on a Bruker DRX-500 and DRX-400 spectrometer (Bruker). The chemical shifts $(\delta)$ are reported in ppm using tetramethylsilane as an internal standard and the coupling constants $(J)$ are given in Hertz $(\mathrm{Hz})$. HRESI-MS spectra were recorded on Agilent G3250AA (Agilent) and AutoSpec Premier P776 spectrometers (Waters). Column chromatography (CC) was performed on self-packed open columns with silica gel from Qingdao Haiyang Chemical Co., Ltd (QHCC). Thin layer chromatography (TLC) analyses were conducted on glass sheets of silica gel $\mathrm{GF}_{254}$ from QHCC and detected under a UV lamp at 254 or $365 \mathrm{~nm}$ and visualized by spraying $8 \%$ phosphomolybdic acid-EtOH solution (w/v) or $5 \%$ vanillin- $\mathrm{H}_{2} \mathrm{SO}_{4}(\mathrm{w} / \mathrm{v})$ followed by heating, or visualized with iodine $\left(\mathrm{I}_{2}\right)$. Semipreparative high performance liquid chromatography (HPLC) (Agilent 1200 Series) was performed on an YMC $\mathrm{C}_{18}$ column $(250 \mathrm{~mm} \times 10 \mathrm{~mm}, 5 \mu \mathrm{m}$, YMC KarasumaGojo Bldg.). Fractions from all columns were collected by an auto-collecting apparatus and were combined according to TLC analyses. All other solvents and reagents were commercially purchased from Beijing Greenherbs Science and Technology Development Co., Ltd. and distilled prior to use.

\subsection{Fungi Strain and Materials}

The endophytic fungus T. koningiopsis YIM PH30002 was isolated from a 2-year-old healthy $P$. notoginseng plant collected from Wenshan, Yunnan Province, China, in March 2012. Potato Dextrose Agar (PDA) medium (infusion of $200 \mathrm{~g}$ fresh potato, dextrose $15 \mathrm{~g}$, and $1 \mathrm{~L}$ distilled water, agar $15.0 \mathrm{~g}, \mathrm{pH}$ 7.0) was used for isolation of the fungus and maintenance of the culture for identification purposes. The stock culture of $T$. koningiopsis YIM PH30002 was grown on the PDA slant at $4{ }^{\circ} \mathrm{C}$. Microbial identification was performed with rDNA-ITS molecularphylogenetic analysis and morphology characteristics in different growth stages. The BLAST sequenced data have been deposited at GenBank (Accession No. KM190127). A voucher specimen (No. YIM PH30002) was preserved at the Yunnan Institute of Microbiology, Kunming, China.

\subsection{Fermentation of T. koningiopsis YIM PH30002}

Trichoderma koningiopsis YIM PH30002 was maintained on the fresh PDA medium. Small agar plugs (approximately $5 \times 5 \mathrm{~mm}$ ) with the fungus were cultured in $0.5-\mathrm{L}$ Erlenmeyer flasks containing $100-\mathrm{mL}$ potato dextrose broth (PDB, potato infusion of $200 \mathrm{~g}$ fresh potato, dextrose $15 \mathrm{~g}$, distilled water $1.0 \mathrm{~L}, \mathrm{pH} 7.0$ ) at $130 \mathrm{rpm}$ and $28{ }^{\circ} \mathrm{C}$ for
3 days. Large-scale culture was performed by transferring a-10 $\mathrm{mL}$ of seed culture into an 1-L Erlenmeyer flask containing $250 \mathrm{~mL}$ of PDB and incubated at $130 \mathrm{rpm}$ and $28{ }^{\circ} \mathrm{C}$ for 10 days.

\subsection{Extraction and Isolation}

The production culture $(50 \mathrm{~L})$ was centrifuged to separate mycelia from the supernatant. The supernatant was exhaustively extracted with EtOAc, yielding $30.6 \mathrm{~g}$ of extract. The mycelia were extracted three times with a mixture of $80 \%$ acetone in $\mathrm{H}_{2} \mathrm{O}$ with ultrasonic processing $(53 \mathrm{kHz}, 180 \mathrm{~W})$ for $15 \mathrm{~min}$ each time. Acetone was removed under vacuum, and the resulting aqueous layer $(800 \mathrm{~mL})$ was extracted three times with an equal volume of EtOAc to yield mycelial extract $(13 \mathrm{~g})$. The extracts of the fermentation broth and the mycelia were combined after TLC and HPLC analysis. The organic extract was repartitioned between petroleum ether and $10 \%$ aqueous $\mathrm{MeOH}$ to remove lipids and pigments. The aqueous $\mathrm{MeOH}$ extract was dried under vacuum to yield extract (18.6 g). This extract was fractionated by column chromatography on silica gel $(7 \mathrm{~cm} \times 30 \mathrm{~cm}, 200-300$ mesh, $0.6 \mathrm{~kg}$, flow rate at $30 \mathrm{~mL} / \mathrm{min}$ ) eluting with a stepwise gradient using 2 $\mathrm{L}$ of $\mathrm{CHCl}_{3} / \mathrm{MeOH}$ at ratios of 1:0, 100:1, 50:1, 20:1, 10:1, $5: 1$, and $0: 1 v / v$, and a total of seven fractions (Fr. 1-Fr. 7) were collected. Fraction Fr. 1 (5 g) was eluted with a Sephadex LH-20 column $(6 \mathrm{~cm} \times 70 \mathrm{~cm}$, methanol, $0.4 \mathrm{~L}$ each, flow rate at $7 \mathrm{~mL} / \mathrm{min}$ ) to give four sub-fractions (Fr. 1.1-Fr. 1.4). Compounds 1 (7.2 $\left.\mathrm{mg}, \mathrm{t}_{\mathrm{R}}=14.4 \mathrm{~min}\right)$ and 6 (2.6 $\mathrm{mg}, \mathrm{t}_{\mathrm{R}}=23.0 \mathrm{~min}$ ) were purified by semipreparative HPLC with gradient eluted with $\mathrm{MeOH}-\mathrm{H}_{2} \mathrm{O}(3.0 \mathrm{~mL} / \mathrm{min}$, 50-80 \%, $40 \mathrm{~min}$ ) from sub-Fr. 1.1. Compound 8 (8.7 mg, $\mathrm{t}_{\mathrm{R}}=16.2 \mathrm{~min}$ ) was purified by semipreparative HPLC with gradient eluted with $\mathrm{MeOH}-\mathrm{H}_{2} \mathrm{O} \quad(3.0 \mathrm{~mL} / \mathrm{min}$, $50-68 \%, 40 \mathrm{~min})$ from sub-Fr. 1.2. Fr.2 (8 g) was fractioned by column chromatography on MCI gel gradient eluted with $\mathrm{MeOH}-\mathrm{H}_{2} \mathrm{O}(20-100 \%)$ to give nine subfractions (Fr. 2.1-Fr. 2.9). Compounds 2 (2.2 mg, $\left.\mathrm{t}_{\mathrm{R}}=17.8 \mathrm{~min}\right)$ and $\mathbf{5}\left(2.6 \mathrm{mg}, \mathrm{t}_{\mathrm{R}}=20.5 \mathrm{~min}\right)$ were purified by semipreparative HPLC with gradient eluted with $\mathrm{MeOH}-\mathrm{H}_{2} \mathrm{O}$ (3.0 mL/min, 30-75 \%, $45 \mathrm{~min}$ ) from sub-Fr. 2.1. Compound $4\left(2.4 \mathrm{mg}, \mathrm{t}_{\mathrm{R}}=18.4 \mathrm{~min}\right)$ was purified by semipreparative HPLC with gradient eluted with $\mathrm{MeOH}-$ $\mathrm{H}_{2} \mathrm{O}$ (3.0 $\left.\mathrm{mL} / \mathrm{min}, 35-65 \%, 45 \mathrm{~min}\right)$ from sub-Fr. 2.2. The sub-fraction Fr. 2.4 (0.6 g) was eluted upon Sephadex LH20 (methanol, $0.3 \mathrm{~L}$ each at a flow rate $4 \mathrm{~mL} / \mathrm{min}$ ) and further purified by semipreparative HPLC with gradient eluted with $\mathrm{MeOH}-\mathrm{H}_{2} \mathrm{O}$ (3.0 mL/min, 35-50\%, $45 \mathrm{~min}$ ) to afford compounds $3\left(3.3 \mathrm{mg}, \mathrm{t}_{\mathrm{R}}=18.6 \mathrm{~min}\right)$ and 7 $\left(3.2 \mathrm{mg}, \mathrm{t}_{\mathrm{R}}=22.6 \mathrm{~min}\right)$. 


\subsubsection{Koninginin $N(\mathbf{1})$}

Pale-yellow oil; $[\alpha]_{\mathrm{D}}^{20}-68.3 \quad(c=0.2, \mathrm{MeOH}) ; \quad \mathrm{UV}$ $(\mathrm{MeOH}) \lambda_{\max }(\log \varepsilon) 250 \mathrm{~nm}(4.12) ;{ }^{1} \mathrm{H}$ and ${ }^{13} \mathrm{C} \mathrm{NMR}$ data, see Table 1; HRESI-MS m/z: $303.1579[\mathrm{M}+\mathrm{Na}]^{+}$ (calcd for $\mathrm{C}_{16} \mathrm{H}_{24} \mathrm{O}_{4} \mathrm{Na} 303.1572$ ).

\subsubsection{Koninginin $O(2)$}

Pale-yellow oil; $[\alpha]_{\mathrm{D}}^{20} 1.6(c=0.1, \mathrm{MeOH})$; UV $(\mathrm{MeOH})$ $\lambda_{\max }(\log \varepsilon) 253 \mathrm{~nm}(3.91) ;{ }^{1} \mathrm{H}$ and ${ }^{13} \mathrm{C}$ NMR data, see Table 1; HRESI-MS m/z: $303.1569[\mathrm{M}+\mathrm{Na}]^{+}$(calcd for $\mathrm{C}_{16} \mathrm{H}_{24} \mathrm{O}_{4} \mathrm{Na}$ 303.1572).

\subsubsection{Koninginin $P(3)$}

Pale-yellow oil; $[\alpha]_{\mathrm{D}}^{20}-3.8(c=0.1, \mathrm{MeOH}) ; \mathrm{UV}(\mathrm{MeOH})$ $\lambda_{\max }(\log \varepsilon) 256 \mathrm{~nm}(4.05) ;{ }^{1} \mathrm{H}$ and ${ }^{13} \mathrm{C}$ NMR data, see Table 1; HRESI-MS m/z: $321.1675[\mathrm{M}+\mathrm{Na}]^{+}$(calcd for $\left.\mathrm{C}_{16} \mathrm{H}_{26} \mathrm{O}_{5} \mathrm{Na} 321.1678\right)$.

\subsubsection{Koninginin $Q(4)$}

Pale-yellow oil; $[\alpha]_{\mathrm{D}}^{20} 36.1(c=0.2, \mathrm{MeOH}) ; \mathrm{UV}(\mathrm{MeOH})$ $\lambda_{\max }(\log \varepsilon) 256 \mathrm{~nm}(3.87) ;{ }^{1} \mathrm{H}$ and ${ }^{13} \mathrm{C}$ NMR data, see Table 1; HRESI-MS m/z: $335.1838[\mathrm{M}+\mathrm{Na}]^{+}$(calcd for $\left.\mathrm{C}_{17} \mathrm{H}_{28} \mathrm{O}_{5} \mathrm{Na} 335.1834\right)$.

\subsection{Antimicrobial Activity, NO Inhibitory Activity, and Anticoagulant Activity Assays}

The antimicrobial activities of compounds 1-8 were evaluated with the methods described in NCCLS standard M27-A2 and M7-A7 [17, 18]. Nystatin (Taicheng Pharmaceutical Co., Ltd., purity $>99 \%$ ) were employed as positive controls in the antifungal assays, respectively. All experiments were treated in triplicate. The microbial growth was observed with a CX21BIM-set5 microscope (Olympus Corp). MIC was determined as the lowest concentration that produced complete growth inhibition of the tested microorganism.

The NO inhibitory activity of $\mathbf{1}$ was determined using the Griess reagent assay for NO production [19]. Briefly, the murine macrophage cell line was used as detection model. The supernatants were used to measure the NO production with an MTT [3-(4,5-dimethylthiazol-2-yl)-2,5diphenyltetrazoliumbromide] assay for cell viability. MG132 (proteasome inhibitor) was used as the positive control.

The in vitro anticoagulant activity of compound $\mathbf{5}$ was investigated by the method of activated partial thromboplastin time (APTT) [20]. Low molecular weight heparin (LMWH) was used as the positive control.

Acknowledgments This work was supported partly by grants from the National Natural Science Foundation of China (Nos. 81360480, 21262041 and 81460536).

\section{Compliance with Ethical Standards}

Conflict of interest The authors declare no competing financial interest.

Open Access This article is distributed under the terms of the Creative Commons Attribution 4.0 International License (http:// creativecommons.org/licenses/by/4.0/), which permits unrestricted use, distribution, and reproduction in any medium, provided you give appropriate credit to the original author(s) and the source, provide a link to the Creative Commons license, and indicate if changes were made.

\section{References}

1. G. Strobel, B. Daisy, Microbiol. Mol. Biol. Rev. 67, 491-502 (2003)

2. G.J. Samuels, Mycol. Res. 100, 923-935 (1996)

3. I.S. Druzhinina, V. Seidl-Seiboth, A. Herrera-Estrella, B.A. Horwitz, C.M. Kenerley, E. Monte, P.K. Mukherjee, S. Zeilinger, I.V. Grigoriev, C.P. Kubicek, Nat. Rev. Microbiol. 9, 749-759 (2011)

4. J. Kuc, Eur. J. Plant Pathol. 107, 7-12 (2001)

5. C. Keswani, S. Mishra, B.K. Sarma, S.P. Singh, H.B. Singh, Appl. Microbiol. Biotechnol. 98, 533-544 (2014)

6. J.L. Reino, R.F. Guerrero, R. Hernandez-Galan, I.G. Collado, Phytochem. Rev. 7, 89-123 (2008)

7. L. Chen, Y.T. Liu, B. Song, H.W. Zhang, G. Ding, X.Z. Liu, Y.C. Gu, Z.M. Zou, Fitoterapia 96, 115-122 (2014)

8. Y. Sun, L. Tian, J. Huang, H.Y. Ma, Z. Zheng, A.L. Lv, K. Yasukawa, Y.H. Pei, Org. Lett. 10, 393-396 (2008)

9. F.H. Song, H.Q. Dai, Y.J. Tong, B. Ren, C.X. Chen, N. Sun, X.Y. Liu, J. Bian, M. Liu, H. Gao, H.W. Liu, X.P. Chen, L.X. Zhang, J. Nat. Prod. 73, 806-810 (2010)

10. P. Cao, J. Yang, C.P. Miao, Y.J. Yan, Y.T. Ma, X.N. Li, L.X. Zhao, S.X. Huang, Org. Lett. 17, 1146-1149 (2015)

11. J.L. Chen, K. Liu, C.P. Miao, S.Z. Sun, Y.W. Chen, L.H. Xu, H.L. Guan, L.X. Zhao, Ann. Microbiol. (2015). doi:10.1007/ s13213-015-1171-5

12. G. Liu, Z.Q. Wang, Synthesis 1, 119-127 (2001)

13. S.R. Parker, H.G. Cutler, P.R. Schreiner, Biosci. Biotechnol. Biochem. 59, 1747-1749 (1995)

14. X.X. Zhou, J. Li, Y.H. Yang, Y. Zeng, P.J. Zhao, Phytochem. Lett. 8, 137-140 (2014)

15. H. Yamazaki, R. Saito, O. Takahashi, R. Kirikoshi, K. Toraiwa, K. Iwasaki, Y. Izumikawa, W. Nakayama, M. Namikoshi, J. Antibiot. 68, 628-632 (2015)

16. C.P. Miao, X.G. Qiao, Y.K. Zheng, Y.W. Chen, L.H. Xu, H.L. Guan, L.X. Zhao, Plant Dis. 99, 1650 (2015)

17. NCCLS, Reference method for broth dilution antifungal susceptibility testing of yeasts; approved standard. NCCLS document M27-A2 [ISBN 1-56238-469-4], 2nd ed. (NCCLS, Wayne, 2002)

18. Clinical and Laboratory Standards Institute,. Methods for dilution antimicrobial susceptibility tests for bacteria that grow aerobically; approved standard. Clinical and laboratory standards 
institute document M7-A7 [ISBN 1-56238-587-9], 7th ed. (Clinical and Laboratory Standards Institute, Wayne, 2006)

19. M.D. Wu, M.J. Cheng, B.C. Wang, Y.J. Yech, J.T. Lai, Y.H. Kuo, G.F. Yuan, I.S. Chen, J. Nat. Prod. 71, 1258-1261 (2008)
20. A.P.S. Azevedo, J.C. Farias, G.C. Costa, S.C.P. Ferreira, W.C. Aragao-Filho, P.R.A. Sousa, M.T. Pinheiro, M.C.G. Maciel, L.A. Silva, A.S. Lopes, E.S.B. Barroqueiro, M.O.R. Borges, R.N.M. Guerra, F.R.F. Nascimento, J. Ethnopharma. 111, 155-159 (2007) 